\title{
EFFORTS AND INEQUALITY OF OPPORTUNITIES IN THE BOLIVIAN LABOR MARKET
}

\section{Fátima Rico Encinas and Ricardo Nogales Carvajal}

\section{ABSTRACT}

The equitable distribution of income, along with human development indices, is among the factors that differentiate developed from developing countries. In this paper, efforts and other variables related to the circumstances of individuals were quantified and analyzed together with traditional determinants in order to explain inequality in the working population of Bolivia. We estimated econometric models by merging the extended Mincer equation with John Roemer's theory of Inequality of Opportunity. We find that efforts are important determinants of the levels of wage inequality in the country as well as regional development, labor informality, gender and ethnicity. In this sense, the paper separates the part of wage inequality that may be attributed to situations that are beyond the control of individuals and that can be attributed to conscious decisions. Micro simulations determined that it would be possible to reduce inequality by as much as $21 \%$ if it gives people the chance to make similar efforts to improve their wages.

Keywords: Inequality, Quality of Life, Labor Income, Micro simulations. 